\title{
Feelings of satisfaction in mature students of financial accounting in a virtual learning environment: an experience of measurement in higher education
}

Teresa C. Herrador-Alcaide ${ }^{\text {* }^{*}}$, Montserrat Hernández-Solís ${ }^{1}$ and Ramon Sanguino Galván ${ }^{2}$

\author{
* Correspondence: therrador@cee. \\ uned.es \\ ${ }^{1}$ Department of Business Economics \\ and Accounting, Faculty of \\ Economics and Business, \\ Universidad Nacional de Educación \\ a Distancia (UNED), Madrid, Spain \\ Full list of author information is \\ available at the end of the article
}

\begin{abstract}
Currently, the usefulness of ICT (Information and Communication Technologies) in the teaching-learning process has not been discussed; unlike distance learning, these new tools are used via technologies. The current approach to social development, supported by the exercise of innovation, learning and research, is undeniable. Within this framework, student satisfaction regarding blended e-learning has been studied. However, in distance university models, which are supported by virtual platforms, it is necessary to ask ourselves the following question: are students satisfied when they are not in a face-to-face classroom environment?

The objective of this study is to analyse students' perceptions of their satisfaction levels in a virtual learning environment. In this evaluation, the students' generic skills were also considered, as well as their perception of the learning environment. The findings of the analysis seem to reveal that students have a high perception of satisfaction, considering students' perception and learning experience as a proxy of the feeling of satisfaction. Students' perceptions of the virtual learning environment and of their own skill, which also takes on high values, could have some type of effect on their overall satisfaction. A significant finding is that students with a high positive perception of their generic skills are also satisfied with the learning process and with the virtual learning environment. The validity of the three construct designed to measure the latent variables - feelings of satisfaction, acceptance of the virtual learning environment and students' self-perception on their generic skills-ensures their usefulness as variables of measurement.
\end{abstract}

Keywords: Accounting learning, Virtual learning environment, Learning satisfaction, learning skills, distance learning

\section{Introduction and theoretical framework}

Teaching technologies offer a wide range of possibilities to be applied to learning processes (Cortina-Pérez, 2008; Garrison \& Anderson, 2005), which have been increased by the use of open resources in education and by their impact on higher education, especially for developing countries (United Nations Educational, Scientific and Cultural Organisation (UNESCO), 2002). Due to these technologies, a new type of relationship has been established between teacher and student, namely, a relationship that does not

(c) The Author(s). 2019 Open Access This article is distributed under the terms of the Creative Commons Attribution 4.0 International License (http://creativecommons.org/licenses/by/4.0/), which permits unrestricted use, distribution, and reproduction in any medium, provided you give appropriate credit to the original author(s) and the source, provide a link to the Creative Commons license, and indicate if changes were made. 
necessarily require a physical and face-to-face space. Physical spaces for education are being replaced by virtual or blended learning via a virtual learning environment, whose use could offer both advantages and barriers (Kurelovic, 2016; Monereo, 2007). This virtual environment allows students to build and develop their own learning path. In this way, education is considered, in the current approach, as involving the use of widespread technology, such as a smartphone, tablet or computer, applied to education in informal learning (Santos \& Ali, 2012) and lifelong learning (Sharples, 2000), especially with mature students. I is thought that mature students use information and communication technology (ICT) more frequently for academic purposes than for other objectives (Mensah, 2017), perhaps because this environment allows students a more personal optimization of e-tools and learning decisions can be made based on each person's timetable. This social framework for learners and teachers has led to the analysis of users' attitudes as a relevant scientific line of research. The objective is to provide a greater knowledge of the learning and teaching process in higher education (Viberg \& Grönlund, 2013) and, as a consequence, to also accept virtual and technological learning environments (Chen, 2017). Furthermore, research on feelings has traditionally been linked to the success of this current learning environment based on the web (Conati, 2002), mainly through the exploration of the perception of the people's engagement with the learning and reaching process (Van Wyk, 2017), especially students and teachers.

In terms of the accounting market, employers presume that students are prepared for their requirements and have the capacity to adapt to a changing environment (Byrne, Flood, \& Willis, 2002), which implies having the skills to move in online environments, and the ability to familiarize themselves with technological environments (Hall, Ramsay, \& Raven, 2004).

The use of virtual learning environments in universities has advantages over traditional face-to-face teaching in a classroom. Every student can connect from anywhere to receive online training. The virtual learning environment is a fully customized way of studying at any time that offers completely flexible training adapted to everyone's personal needs, which results in greater specialization and the possibility of having virtual contact with the assigned teacher via the use of teaching e-tools, such as digital whiteboards, chats, web-conferences or web-videos. These technologies allow the teacher to offer an almost immediate response. Student feedback in terms of perception and usefulness is stated in student experiences in these virtual learning environments. As Soto and Fernández (2003) note, the use of e-tools in virtual environments provide greater advantages to people with special educational needs, such as those of mature students, who are sometimes excluded from university education due to their social characteristics (Enoch \& Soker, 2006; Tett, 2004). In this way, ICTs facilitate not only the educative inclusion but also the social inclusion of adults through teaching (Requena, 2016) because studying part-time as a mature student can have a profound effect on people's lives (Swain \& Hammond, 2011);supporting this emerging and traditionally overlooked population requires an in-depth understanding of mature students' experiences (Van Rhijn, Lero, Bridge, \& Fritz, 2016).

Virtual students are part of these virtual learning environments. Virtual students require several skills, none of them generic skills, to be successful in the job market (Kavanagh \& Drennan, 2008). These virtual students must be familiar with virtual 
environments and able to use computers, the Internet, chats and other information technology tools to carry out their studies (Martínez-Cerdá, Torrent-Sellens, \& González-González, 2018).

The question that must be asked now is the following: are virtual students satisfied with this virtual teaching model? Some authors consider this satisfaction level to be quite high (Cabero, Llorente, \& Puentes, 2010; Cassidy, 2016), perhaps due to the flexibility (Arbaugh, 2000) and the immediacy of the students' interaction with that model (Al Ghamdi, Samarji, \& Watt, 2016), the perceived self-efficacy regarding its use in computerized learning environments (Navimipour \& Zareie, 2015; Wu, Tennyson, \& Hsia, 2010), or the visual and interactive features embedded in applications (Violante \& Vezzetti, 2015). A virtual environment provides students with absolute autonomy in planning their study and work hours. Only an Internet connection is necessary and one does not even need a computer, as the connection can be made through any electronic devices, such as tablets or smartphones. The work-life balance is better when students controls their study times; being able to study without physical or space restrictions, as everything one needs is included in the virtual course in which one is enrolled.

Currently, the usefulness of ICTs in the teaching-learning process has not been fully discussed, but in a distance-learning model, these online tools are perhaps the sole support for reproducing traditional teaching via technologies. This aspect is a new focus for social development supported by the exercise of innovation, learning and research (Palacios \& Galván, 2003), and it is necessary to analyse the satisfaction of students in blended e-learning (Wu et al., 2010). According to the above, the necessity of carrying out an exploratory analysis to verify the students' perception of three variables involved in this virtual learning method is considered; these variables are self-perception of generic skills [GS], perception of VLE [VLE] and satisfaction perceived [STF] in the EHEA in a distance education model.

\section{Methodology}

\section{e-tools and the virtual learning environment}

Virtual learning environments can be generic and are based on open platforms that provide their own electronic tools for learning. However, when applied to official degree studies primarily supported by e-learning, the VLE is usually designed ad hoc for such degrees. Even when the VLE is self-developed, tools are often included whose benefits have already been corroborated as suitable for virtual learning environments. In this way, the use of video applied to teaching as a habitual teaching tool in new environments has been studied and corroborated (Brecht, 2012; Brecht \& Ogilby, 2008; Holtzblatt \& Tschakert, 2011; Stanley \& Edwards, 2005), has been tested, and allows one to learn in more visual forms; these videos are perceived as powerful learning tools by students (Henderson, Selwyn, \& Aston, 2017). Another common tool is chats and online forums, which are used to connect students and thus improve the performance and development of certain skills (Potter \& Johnston, 2006), as these allow users to overcome the physical distance between teacher and student through online tutoring (Cano, 2009; Castillo, 2008). In a virtual learning environment, there must also be a tool for knowledge self-assessment (Oosterhoff, Conrad, \& Ely, 2008) because it is essential to improve one's autonomous online learning and maximize opportunities and performance through training (Rodríguez \& Ibarra, 2011). 
The research has been carried out at the Universidad Nacional de Educación a Distancia (UNED) in a Tourism Degree programme, in the subject of accounting. The UNED has over 40 years of experience in distance education and distance learning with large student groups.

The students are mainly mature students, with families and jobs, who joined the university at an older age. These students have limited time and require resources that allow them to take full advantage of their study time. In addition, some of these students are less skilled in the use of online tools due to their late access to the university or their lack of knowledge. The average age of students is approximately 36 years old.

Since its founding, the university has applied a blended learning system using its own methodology designed ad hoc for its studies. The teaching is supported by a structure of associated centres distributed in multiple locations in Spain and abroad, as well as in the VLE that was developed ad hoc. Students can thus opt to attend "face-to-face" sessions in the university-associated centre, online activities in the VLE, or both. These methods are not exclusive but complementary, providing a voluntary classroom option for students.

In fact, many students interact and learn via the virtual environment due to their characteristics as mature students and the limited time they have to spend in a traditional face-to-face class.

In recent years, the methodology has been reinforced by the application of online tools to enhance engagement and mitigate abandonment. In this sense, although all the subjects taught in the university share a similar VLE structure, teachers are developing and testing various online resources, exploring teaching innovations for the most appropriate tools for each subject. That is the reason why we refer to these online methods as new tools, because they are new resources and are being used in a new way, or simply because they are new tools for mature students.

In this way, the VLE within which this research has been developed is supported by a platform that allows the application of a set of e-tools considered useful for the development of virtual teaching, as seen in Fig. 1, among which are included online questionnaires to assess knowledge, forums to interconnect students and teachers, videos applied to teaching, and other e-tools. These tools were available on an IT platform (aLF). Via this platform, every student could access the VLE and manage all the resources without restriction of physical or temporal learning space. Our VLE combines tools, resources, contents, educational assistance and discussions. Despite the advantages of virtual learning environments, student acceptance is perhaps the most important factor for success (Martins \& Kellermanns, 2004), hence the need to analyse the satisfaction of learning in virtual environments in a distance education model online.

For the above reasons, these kinds of resources were made available online for students studying financial accounting in a tourism programme.

\section{Sample and questionnaire}

To answer questions about the satisfaction with and acceptance of virtual learning environments, researchers have analysed students' perceptions through a survey (Al-Samarraie, Teng, Alzahrani, \& Alalwan, 2017). Like previous research, in this paper, student satisfaction has been examined as an indicator of whether learners are satisfied with their learning experience (Li, Marsh, Rienties, \& Whitelock, 2016; Richardson, 


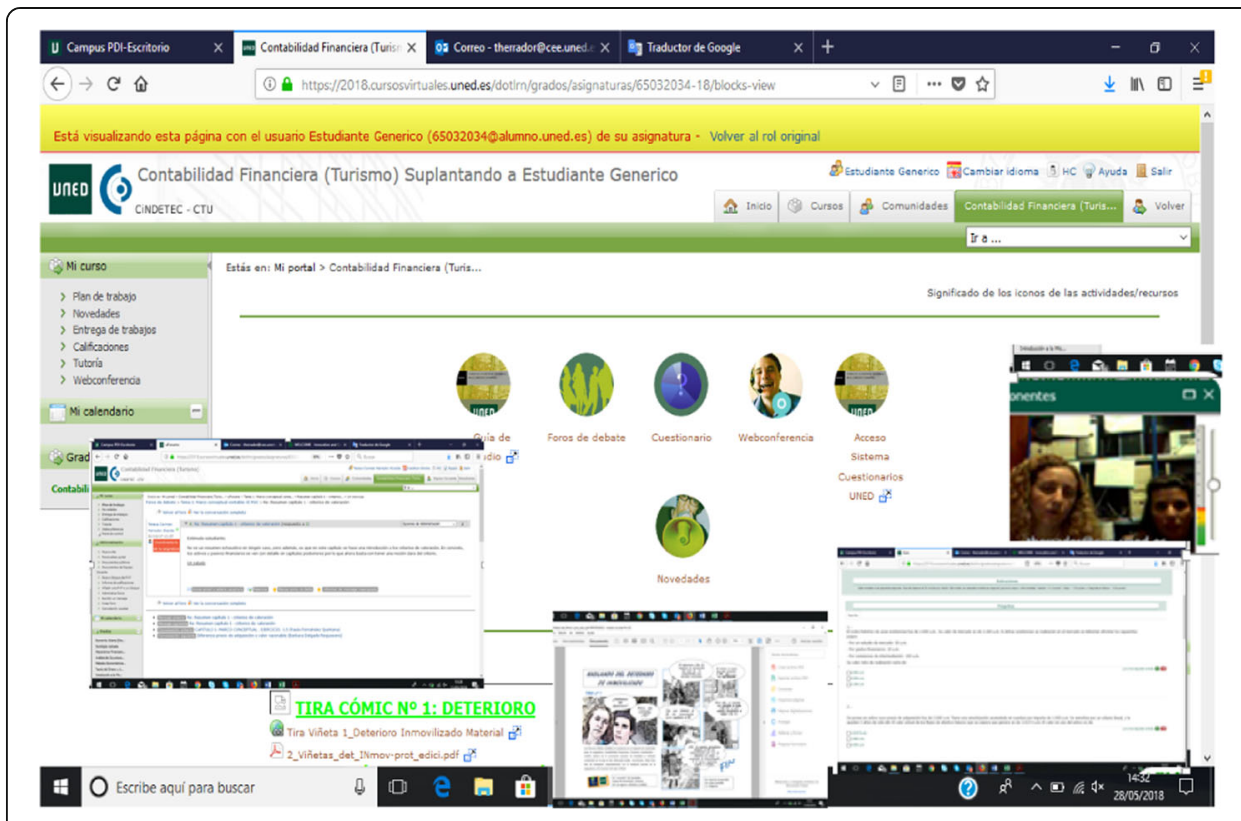

Fig. 1 Virtual Learning Environment

Maeda, Lv, \& Caskurlu, 2017) using perceived satisfaction as a proxy of the latent variable of the feeling of satisfaction via a questionnaire (Kang, Park, Jung, \& Park, 2009).

At the end of the term, the students' perception was measured in relation to various aspects of the teaching-learning process in the VLE using an online questionnaire developed ad hoc as in previous studies (Boza \& Toscano, 2012; Herrador-Alcaide \& Hernández-Solís, 2017; Hurtado \& Lara, 2015).

The study was conducted taking as a population students studying the subject of accounting in a tourism degree programme. The number of students enrolled was nearly 500 students. All students could participate in the VLE and use different e-tools. At the end of the academic period, a survey was circulated to all students. The number of students who answered the questionnaire was 146 students. The number of valid questionnaires answered was 134 questionnaires, which were collected during 2017. These valid questionnaires were limited to those students who used multimedia resources and who correctly completed the questionnaire. As a consequence, the sample comprised approximately $30 \%$ of all students.

Some of the sociodemographic characteristics of the sample are shown in Table 1.

The questionnaire was designed to group items into several dimensions: one dimension was related to the student's aptitude for the VLE, another dimension was related to the self-perception of the fulfilment of the generic skills defined for the studies, and a third dimension was related to their perception of satisfaction with learning in the environment.

All items took a value using a Likert scale of 1 to 5 (" 1 " = "Strongly disagree" to " 5 "= "Strongly agree"). Once the initial questionnaire was constructed, it was reviewed by professors in accounting, education and psychology to ensure its validity. Using feedback from these experts, some items were modified or eliminated. Several full-time professors with extensive experience in university teaching, both face-to-face and in blended learning, participated in the prior review process. Teachers were consulted not only from the university involved but from other universities. These teachers were 
Table 1 Sociodemographic characteristics

\begin{tabular}{|c|c|c|c|c|c|}
\hline \multicolumn{6}{|c|}{ Gender } \\
\hline & & $\begin{array}{l}\text { Statistical } \\
\text { Frequency (SF) }\end{array}$ & $\begin{array}{l}\text { Percentage } \\
\text { (p) }\end{array}$ & $\begin{array}{l}\text { Valid } \\
\text { Percentage } \\
\text { (VP) }\end{array}$ & $\begin{array}{l}\text { Accumulated } \\
\text { Percentage (AP) }\end{array}$ \\
\hline \multirow[t]{4}{*}{ Valid } & Female & 97 & 72,4 & 72,4 & 72,4 \\
\hline & Male & 36 & 26,9 & 26,9 & 99,3 \\
\hline & Do not want to answer & 1 &, 7 & , 7 & 100,0 \\
\hline & Total & 134 & 100,0 & 100,0 & \\
\hline \multicolumn{6}{|c|}{ Level of previous studies completed } \\
\hline & & SF & $P$ & VP & $\mathrm{AP}$ \\
\hline \multirow[t]{6}{*}{ Valid } & University studies & 20 & 14,9 & 14,9 & 14,9 \\
\hline & Master & 19 & 14,2 & 14,2 & 29,1 \\
\hline & $\begin{array}{l}\text { University entrance examination } \\
\text { for over } 25 \text { years }\end{array}$ & 19 & 14,2 & 14,2 & 43,3 \\
\hline & $\begin{array}{l}\text { University entrance examination } \\
\text { for over } 45 \text { years }\end{array}$ & 4 & 3,0 & 3,0 & 46,3 \\
\hline & $\begin{array}{l}\text { University access exam after } \\
\text { High School }\end{array}$ & 72 & 53,7 & 53,7 & 100,0 \\
\hline & Total & 134 & 100,0 & 100,0 & \\
\hline \multicolumn{6}{|c|}{ Part-time students for work } \\
\hline & & SF & $P$ & VP & PA \\
\hline \multirow[t]{3}{*}{ Valid } & No & 15 & 11,2 & 11,2 & 11,2 \\
\hline & Yes & 119 & 88,8 & 88,8 & 100,0 \\
\hline & Total & 134 & 100,0 & 100,0 & \\
\hline
\end{tabular}

Source: own development by SPSS

selected among people with experience in research and publication in the field, each in relation to their specialty. These professors specifically reviewed the validity of the questionnaire, both in content and in the methodology with which it was to be applied. The bases for this questionnaire had been established over 3 previous academic years. Accordingly, different parts of the methodology, especially the questionnaire and its constructs, had been previously reviewed through debate in both education and accounting congresses. The reviewed questionnaire was piloted with a small group of students to once again ensure the comprehension and validity of items as an instrument to measure students' perception, as is usual in educational research (Alsadoon, 2017; Chang, Hajiyev, \& Su, 2017).

The questionnaire content applied to this research had been previously validated and the reliability ensured by the Alpha-Cronbach test as shown in Table 2. The minimum value for reliability in social sciences research should be 0.7 (Chen, Chen, \& Kinshuk, 2009). Items in this study have good reliability and discriminant validity.

When a set of items with the same unit of measurement is used, the interpretation is performed with the reliability of the value of Cronbach's alpha, based on the correlation between the items, so that the higher it is, the more likely it is that the instrument will be consistent (Frías-Navarro, 2014).

When Cronbach's alpha takes values from 0.7, it is considered valid for data inference (George \& Mallery, 2003). However, even when inferior, when Cronbach's alpha is very close to 0.7 , it can be accepted as valid in prospective research in the establishment of 
Table 2 Reliability by Cronbach

\begin{tabular}{|c|c|c|}
\hline \multicolumn{3}{|c|}{ Reliability for Generic Skills } \\
\hline Alfa Cronbach & Standardized Alfa Cronbach & Number of items \\
\hline ,674 & ,686 & 5 \\
\hline \multicolumn{3}{|c|}{ Reliability for students' perception on satisfaction related to e-learning process } \\
\hline e-Alfa Cronbach & Standardized Alfa Cronbach & N \\
\hline ,902 & ,905 & 5 \\
\hline \multicolumn{3}{|c|}{ Reliability for students' perception on virtual learning environment } \\
\hline Alfa Cronbach & Standardized Alfa de Cronbach & $N$ \\
\hline 797 &, 803 & 7 \\
\hline
\end{tabular}

Source: own development by SPSS

initial conclusions (Nunnally, 1967; Nunnally, 1978). Moreover, Loewnthal (1996) suggested that a reliability value of 0.6 can be considered acceptable for scales with fewer than 10 items. For all previous arguments, the Cronbach values of this study support the conclusions of this investigation.

\section{Variables and items}

The items measuring students' perceptions of the VLE were based on previous studies on functionality and interaction (Chen \& Jones, 2007; Herrador-Alcaide \& Hernández-Solís, 2016; Johnston, Killion, \& Oomen, 2005; Kreijns, Kirschner, \& Jochems, 2003; Levy, 2007; Pituch \& Lee, 2006; Van Raaij \& Schepers, 2008). This dimension comprised 7 items (variable $<<$ VLEi $>>$ ). Satisfaction with learning was reviewed in previous studies (Chiu, Hsu, \& Sun, 2005; Wu \& Wang, 2005), and for skills (Gámiz-Sánchez \& Gallego-Arrufat, 2016; Harnar, Brown, \& Mayall, 2000; Martínez, Pérez, \& Martínez, 2016), which included generic or general skills as defined in the Official Memory of the Degree. Hence, these dimensions comprised 5 items for both (variables $<<\mathrm{STFi}>>$ and $<<$.GSi $>>$ for satisfaction and generic skill respectively), as seen in Table 3 and Fig. 2.

The items measuring students' perceptions of the VLE were based on previous studies on functionality and interaction (Herrador-Alcaide \& Hernández-Solís, 2017; Johnston et al., 2005; Kreijns et al., 2003; Pituch \& Lee, 2006; Levy, 2007; Chen, \& Jones, 2007; Van Raaij \& Schepers, 2008). This dimension comprised 7 items (variable $<<$ VLEi $>>$ ). Satisfaction regarding learning previous research was reviewed (Chiu et al., 2005; Wu \& Wang, 2005), and for skills (Gámiz-Sánchez \& Gallego-Arrufat, 2016; Harnar et al., 2000; Martínez et al., 2016), which included generic or general skills as defined in the Official Memory of the Degree. Hence, these dimensions comprised 5 items for both (variables $<<$ $\mathrm{STFi}>>$ and $<<\mathrm{GSi}>>$ for satisfaction and generic skill respectively), at seen in Table 3. The strong correlation among variables is expected, as shown in Fig. 2.

\section{Results}

The first results show that the perceived satisfaction of learning by the students is high, with a score of approximately 4 on a Likert scale of 1 to 5 , where 5 is the highest score. The self-perception of their generic skills also scored an approximate average of 4 points, while the perception of their attitude towards the VLE was slightly lower. 
Table 3 Items

\begin{tabular}{ll}
\hline Self-perception of generic skills & \\
GS1 & My ability to solve problems \\
GS2 & My analytical skills \\
GS3 & My ability to work in a group \\
GS4 & My written communication skills \\
GS5 & My ability to plan my own work
\end{tabular}

Students' perception on satisfaction related to e-learning process

$\begin{array}{ll}\text { STF1 } & \text { I have learned a lot with the course of Financial Accounting (Tourism) } \\ \text { STF2 } & \text { I do not regret the time invested in this subject } \\ \text { STF3 } & \text { I feel that I have learned useful knowledge for business management } \\ \text { STF4 } & \text { I have had a feeling of reaching achievements in my learning as I progressed } \\ \text { STF5 } & \text { I would encourage others to take the subject }\end{array}$

Students' perception on virtual learning environment

\begin{tabular}{ll} 
VLE1 & E-learning encourages more active learning than traditional classes \\
VLE2 & I enjoy using personal computers and similar devices \\
VLE3 & My experience in using electronic devices (computers, tablets, smart phones ...) \\
& has helped me move in the virtual space of the subject \\
VLE4 & I usually use electronic devices in virtual environments \\
VLE5 & I do not feel intimidated in virtual learning environments (e-learning) \\
VLE6 & In a virtual classroom I feel more comfortable than in a face to face classroom \\
VLE7 & The e-learning allows you to learn at your own pace \\
\hline
\end{tabular}

Source: own development

\section{Students' perception of generic skills}

The descriptive dimensions related to the self-perception of the students in relation to their generic abilities indicate that students perceive they possess the generic skills at a high level (close to 4 points out of 5). The statistic mean of all the items of the generic skill constructor is 3.7 points out of 5 . The ability to organize their own work stands out as the best skill, as shown in Tables 4 and 5 .

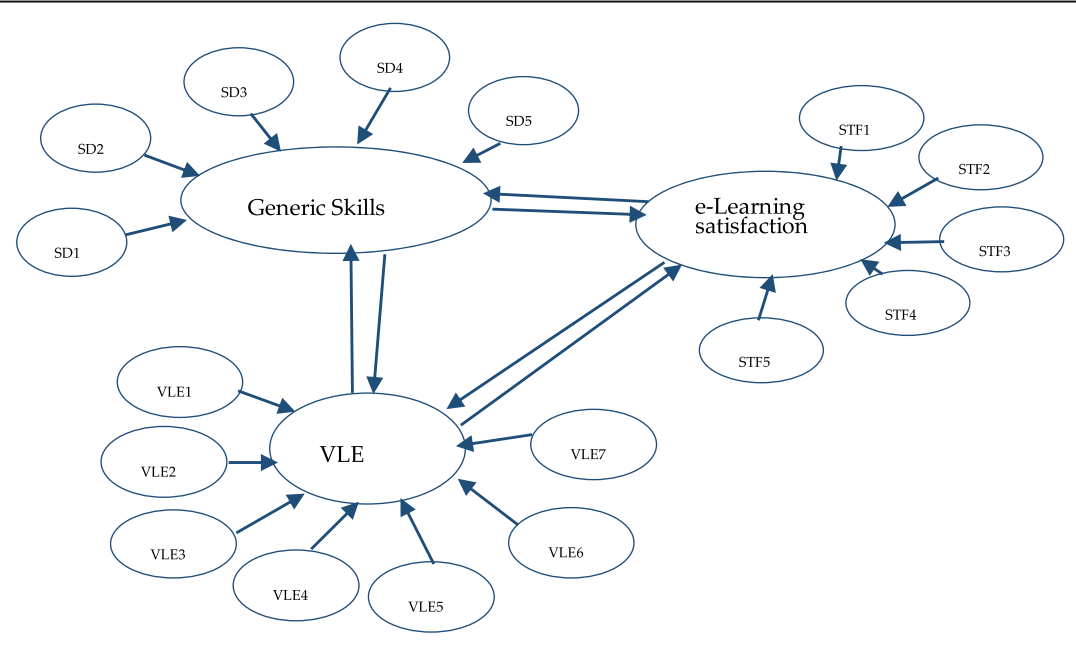

Source: own development by SPSS

Fig. 2 Model. Source: own development by SPSS 
Table 4 Statistics of items on Generic Skills

\begin{tabular}{llll}
\hline & Mean & SD & N \\
\hline GS1 & 3,70 &, 859 & 134 \\
GS2 & 3,49 &, 802 & 134 \\
GS3 & 3,79 & 1034 & 134 \\
GS4 & 3,75 &, 888 & 134 \\
GS5 & 3,86 & 1098 & 134 \\
\hline
\end{tabular}

Source: Own development by SPSS

The correlation between the items (second order variables) is positive $\left(0^{\prime} 3\right)$. Hence, the Pearson coefficient indicates that there is a bivariate linear association between the generic and positive generic items. However, the percentage of linear association is low, except for the linear relationship between GS1 and GS2 $(0,641)$. That is, there is a high association between the self-perception of one's ability to solve problems and the analytical skills possessed by students, and this behaviour can be adjusted to a linear relationship. The lowest linear association occurs between the ability to work in a group and written communication skills (see Table 6).

\section{Students' perception on virtual learning environment}

The mean in relation to the assessment given to the perception that students have in relation to the VLE is high, 3.7 on a Likert scale of 5, with a variance of 1.13. The correlation and the covariance are positive, which indicates that on average the association of variables two to two evolves in the same way (see Tables 7 and 8). The items that scored higher were VL4, VL7 and VL3.

Within this framework, most students recognize that they usually use electronic devices in virtual environments. Likewise, other students place an important value to the fact that the previous use of multimedia devices has facilitated their performance in the VLE of the subject. Also, considering that e-learning helps to learn at your own pace. The lowest score is given to VL6, despite exceeding the statistical median. This low value indicates that the students manifest that they are not in a more comfortable virtual classroom than in a face to face classroom.

The correlation between the variables VLE is positive, that indicates that they evolve in the same way. The item with the highest score is the relationship between VLE3 and VLE4 (0.616), because the habitual use of virtual devices is closely related to the fact that previous experience facilitates the management in the VLE. However, the correlation between VLE5 and VLE7 is low (0.183) (See Table 9).

Table 5 Statistics among elements (GS)

\begin{tabular}{lllllll}
\hline & Mean & Minimum & Maximum & S Range & SD $^{2}$ & N \\
\hline Means among elements & 3719 & 3493 & 3858 &, 366 &, 019 & 5 \\
SD $^{2}$ &, 889 &, 643 & 1205 &, 563 &, 057 & 5 \\
Statistical covariance &, 260 &, 164 &, 441 &, 278 &, 008 & 5 \\
Correlations &, 304 &, 181 &, 641 &, 460 &, 016 & 5 \\
\hline
\end{tabular}


Table 6 Correlations on Generic Skills

\begin{tabular}{llllll}
\hline & GS1 & GS2 & GS3 & GS4 & GS5 \\
\hline GS1 & 1000 &, 641 &, 226 &, 287 &, 293 \\
GS2 &, 641 & 1000 &, 198 &, 256 &, 298 \\
GS3 &, 288 \\
GS4 &, 226 &, 258 & 1000 &, 181 & 1000 \\
GS5 &, 287 &, 296 &, 298 &, 288 & 1000 \\
\hline \multicolumn{2}{l}{ Source: Own development by SPSS } & & & &
\end{tabular}

Source: Own development by SPSS

\section{Students' perception on satisfaction related to e-learning process}

The mean of all the items related to satisfaction is high, with a score of almost 4 out of 5 points. This implies that students, on average, are satisfied with learning in the virtual environment. It cannot be said that any of the relative items to SAT take values that stand out, neither upward nor downward, since they all stand at around 4. This rating could indicate that the satisfaction with learning is valued almost with an "A". The observed SD take similar values also (see Tables 10 and 11).

The correlation between the variables is positive (see Table 12). The highest correlations are between STF4 and SFT1 (0.725) and between STF5 and STF1 (0.726). The lowest correlation is between STF3 and STF1 (0.658). The first correlation implies that students who consider that they have learned a great deal also consider that they have reached their learning goals. The second implies the high correlation between the students who felt that they had learned a great deal and considered they would recommend this course to other students.

The third correlation implies that students who considered that they learned a great deal also considered that their knowledge is useful for business.

To further specify the relationships between the variables of the different constructs, an analysis of bivariate correlations among all the variables was carried out (see Table 13). In this table, the significant correlations at the 0.01 level have been highlighted for each satisfaction variable. Given that we seek to analyse is the satisfaction of the students with the accounting learned through the VLE, according to these results, we consider the following relationships among variables for an extension of the analysis (see Table 14).

Regarding the analysis of correlations among the different variables of satisfaction, generic skills and VLE, a linear regression analysis has been performed to establish the percentage of each satisfaction's variables that is explained linearly by the variables that

Table 7 Statistics of items on VLE

\begin{tabular}{llll}
\hline & Mean & SD & N \\
\hline VLE1 & 3,28 & 1174 & 134 \\
VLE2 & 3,81 & 1098 & 134 \\
VLE3 & 4,19 &, 836 & 134 \\
VLE4 & 4,24 &, 903 & 134 \\
VLE5 & 3,97 & 1176 & 134 \\
VLE6 & 2,87 & 1198 & 134 \\
VLE7 & 4,19 & 1007 & 134 \\
\hline
\end{tabular}

Source: Own development by SPSS 
Table 8 Statistics among elements (VLE)

\begin{tabular}{lllllll}
\hline & Mean & Minimum & Maximum & Range & Variance & N \\
\hline Means & 3795 & 2873 & 4239 & 1366 &, 276 & 7 \\
SD $^{2}$ & 1133 &, 699 & 1435 &, 736 &, 087 & 7 \\
Statistical covariance &, 408 &, 168 &, 670 &, 502 &, 017 & 7 \\
Correlation &, 368 &, 167 &, 616 &, 448 & 3678 & 7 \\
\hline Source: Own development by SPSS & & & & &
\end{tabular}

correlate at the $1 \%$ level with each satisfaction variable. To this end, five multiple linear regressions have been carried out, one for each of the satisfaction variables. The independent variables are all those items that are related in the table with STF1, STF2, STF3, STF4 and STF 5.

Regarding Table 14, the following regressions have been carried out.

\section{Regressions}

R1 :

$\boldsymbol{S T F} 1_{\boldsymbol{t}}=\boldsymbol{\beta}_{1}+\boldsymbol{\beta}_{2} \cdot \mathbf{G S} 1+\boldsymbol{\beta}_{3} \cdot \mathbf{G S} 2+\boldsymbol{\beta}_{4} \cdot \mathbf{G S} 3+\boldsymbol{\beta}_{5} \cdot \mathbf{G S} 4+\boldsymbol{\beta}_{6} \cdot \mathbf{G S} 5+\boldsymbol{\beta}_{7} \cdot V \boldsymbol{L E} 1+\boldsymbol{\beta}_{8} \cdot V \boldsymbol{V E} 2+\boldsymbol{\beta}_{9} \cdot V \boldsymbol{L E} 3+\boldsymbol{\varepsilon}$

In the first explanatory model of satisfaction (STF1), the variables explain $31.7 \%$ of the behaviour of STF1. This result implies that satisfaction with what has been learned cannot be well determined by certain generic skills or by the attitude towards the VLE, since these variables can only explain part of the perceived satisfaction with the contents learned (see Tables 15 and 16).

R2:

$S T F 2_{t}=\beta_{1}+\beta_{2} \cdot G S 1+\beta_{3} \cdot G S 2+\beta_{4} \cdot G S 5+\beta_{5} \cdot V L E 1+\beta_{6} \cdot V L E 2+\beta_{7} \cdot V L E 3+\beta_{8} \cdot V L E 4+\beta_{9} \cdot V L E 7+\beta_{10} \cdot S T F 1+\varepsilon$

In the second model (R2), which measures the satisfaction of the learning process from the perspective of time invested, the explanatory variables can justify almost $45 \%$ of the perception of said satisfaction (see Tables 17 and 18), so these variables will be taken into consideration in future research, for the design and adjustment of the VLE. It must be noted that, in mature university students, time is one of the main limitations to academic performance and, as a consequence, to the persistence in the study.

R3 :

$\operatorname{STF}_{t}=\boldsymbol{\beta}_{1}+\boldsymbol{\beta}_{2} \cdot G S 1+\beta_{3} \cdot G S 2+\beta_{4} \cdot G S 4+\beta_{5} \cdot G S 5+\beta_{6} \cdot V L E 2+\beta_{7} \cdot V L E 7+\beta_{8} \cdot S T F 1+\beta_{9} \cdot S T F 2+\varepsilon$

Table 9 Correlations on VLE

\begin{tabular}{llllllll}
\hline & VLE1 & VLE2 & VLE3 & VLE4 & VLE5 & VLE6 & VLE7 \\
\hline VLE1 & 1000 &, 520 &, 365 &, 418 &, 322 &, 470 &, 443 \\
VLE2 &, 520 & 1000 &, 425 &, 394 &, 258 &, 399 &, 468 \\
VLE3 &, 365 &, 425 & 1000 &, 616 &, 342 &, 167 &, 321 \\
VLE4 &, 418 &, 394 &, 616 & 1000 &, 425 &, 230 &, 288 \\
VLE5 &, 322 &, 258 &, 342 &, 425 & 1000 &, 291 &, 394 \\
VLE6 &, 470 &, 399 &, 167 &, 230 &, 291 & 1000 &, 394 \\
VLE7 &, 443 &, 468 &, 321 &, 288 &, 183 & & 1000 \\
\hline
\end{tabular}

Source: Own development by SPSS 
Table 10 Statistics of items on Satisfaction

\begin{tabular}{llll}
\hline & Mean & SD & N \\
\hline STF1 & 3,88 &, 859 & 134 \\
STF2 & 3,98 & 1058 & 134 \\
STF3 & 4,04 &, 913 & 134 \\
STF4 & 3,91 &, 938 & 134 \\
STF5 & 4,01 & 1004 & 134 \\
\hline
\end{tabular}

Source: Own development by SPSS

R4:

$S T F 4_{t}=\beta_{1}+\beta_{2} \cdot G S 1+\beta_{3} \cdot G S 2+\beta_{4} \cdot V L E 1+\beta_{5} \cdot V L E 2+\beta_{6} \cdot V L E 7+\beta_{7} \cdot S T F 1+\beta_{8} \cdot S T F 2+\beta_{9} \cdot S T F 3+\varepsilon$

The third model (R3) has a high capacity to explain the variable STF3 (see Tables 19 and 20). In the fourth model (R4), which measures the satisfaction with respect to the achievements reached as the students were performing the learning process, the independent variables can explain $65 \%$ of the perception of satisfaction (see Tables 21 and 22).

R5 :

$S T F 5_{t}=\beta_{1}+\beta_{2} \cdot G S 1+\beta_{3} \cdot G S 2+\beta_{4} \cdot V L E 2+\beta_{5} \cdot V L E 7+\beta_{6} \cdot S T F 1+\beta_{7} \cdot S T F 2+\beta_{8} \cdot S T F 3+\beta_{9} \cdot S T F 4+\varepsilon$

In the fifth model (R5), which measures overall satisfaction with the process, independent variables explain almost $70 \%$ of the perception of this satisfaction (see Tables 23 and 24). This result leads us to strengthen this model to limit the variables that condition satisfaction with the accounting learning process in a VLE for mature distance students.

According to the five models related to the different aspects of satisfaction with the online learning process, only the fifth model (R5), for the global satisfaction, shows an explanatory capacity of almost $70 \%$. The focus of the question that supports the variable STF5 and the high adjustment of this fifth model make it possible to summarize the total satisfaction with the process of virtual learning through this model where the direct relationship between each explanatory variable and the dependent variable is shown by the highlighted lines in Fig. 3.

This result is important for the applied educational model, since it allows us to state that the ability to solve problems (GS1) and the analytical skills (GS2) of students are determining factors of satisfaction in the online learning process in accounting. In this sense, the teaching team will assess these skills at the beginning of the academic year,

Table 11 Statistics among elements

\begin{tabular}{lllllll}
\hline & Mean & Minimum & Maximum & Range & SD $^{2}$ & $\mathrm{~N}$ \\
\hline Means among elements & 3964 & 3881 & 4037 &, 157 &, 004 & 5 \\
SD $^{2}$ &, 915 &, 738 & 1120 &, 382 &, 022 & 5 \\
Statistical covariance &, 592 &, 509 &, 686 &, 177 & 1348 & 5 \\
Correlations &, 655 &, 560 &, 752 &, 193 & 1344 & 5 \\
\hline
\end{tabular}

Source: Own development by SPSS 
Table 12 Correlations on Satisfaction

\begin{tabular}{llllll}
\hline & STF1 & STF2 & STF3 & STF4 & STF5 \\
\hline STF1 & 1000 &, 560 &, 658 &, 752 &, 726 \\
STF2 &, 560 & 1000 &, 569 &, 566 &, 588 \\
STF3 &, 658 &, 569 & 1000 &, 698 &, 705 \\
STF4 &, 752 &, 566 &, 698 & 1000 &, 729 \\
STF5 &, 726 &, 588 &, 705 &, 729 & 1000 \\
\hline
\end{tabular}

Source: Own development by SPSS

and we will propose special follow-up activities for students with a low profile in those skills for upcoming years.

It is also important to emphasize that the fact of enjoying the use of computerized environments (VLE2) and being able to mark the study rhythm itself (VLE7) may be related to the problem-solving and analytical capacity characteristics indicated above. This result also leads us to consider that, to increase the overall satisfaction and commitment of the students, customizable actions of analytical learning should perhaps be carried out, so that students are aware of their limitations due to their profile, and they could be oriented to actions that would refurbish the learning process before the learning dropout occurs. Early knowledge of the effect of these profiles relative to generic skills and the VLE itself can also allow teachers to undertake actions to assist and reinforce commitment and prevent dropout from the university.

\section{Discussion and conclusion}

Virtual environments applied to learning are proposed as effective solutions for learning, especially in distance education models. E-learning, despite having detractors and

Table 13 Correlations among variables

GS1 GS2 GS3 GS4 GS5 VLE1 VLE2VLE3 VLE4 VLE5 VLE6VLE7 STF1 STF2 STF3 STF4 STF5

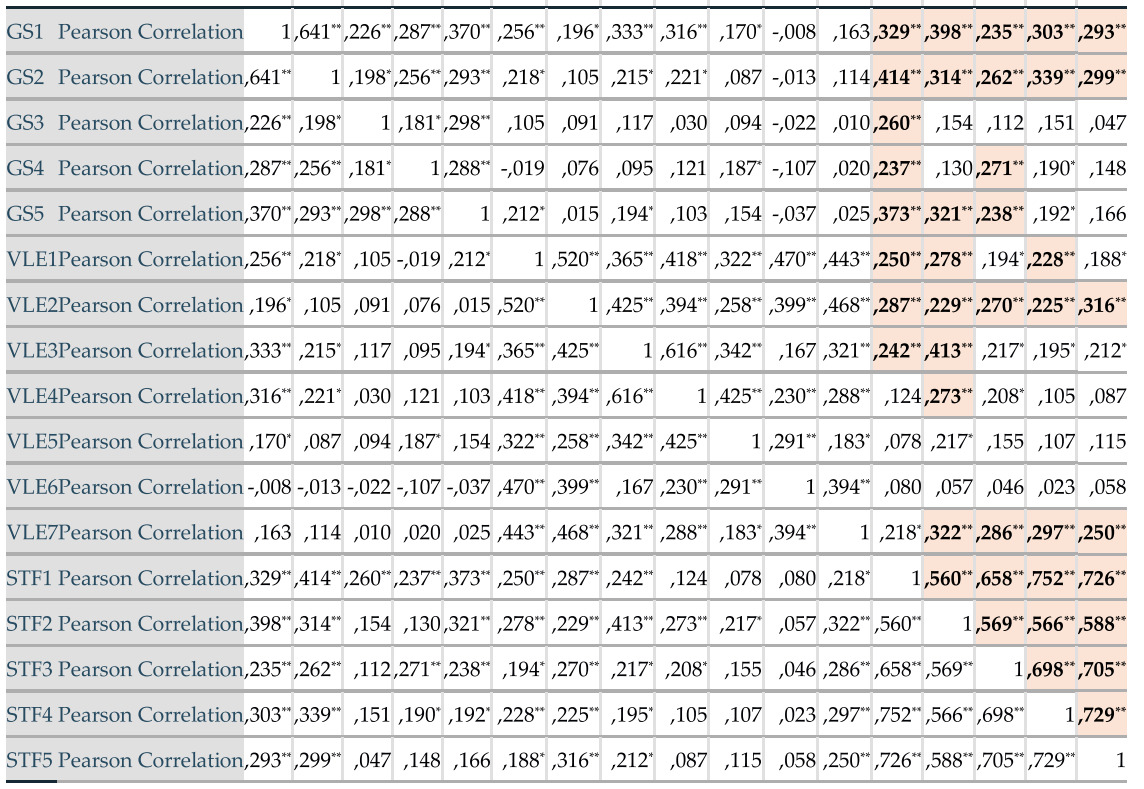

${ }^{a}$ Correlation is significant at the 0.01 level (2-tailed)

${ }^{\mathrm{b}}$ Correlation is significant at the 0.05 level (2-tailed) 
Table 14 Regressions

\begin{tabular}{|c|c|c|c|c|}
\hline \multirow[t]{2}{*}{ Regression } & \multirow{2}{*}{$\begin{array}{l}\text { Dependent } \\
\text { variables }\end{array}$} & \multicolumn{3}{|c|}{ Explanatory variables (correlation at the $1 \%$ level) } \\
\hline & & GS variable & VLE variables & STF variables \\
\hline \multirow[t]{2}{*}{ R1 } & STF1 & GS1, GS2, GS3, GS4, GS5 & VLE1, VLE2, VLE3 & \\
\hline & \multicolumn{4}{|c|}{$\operatorname{STF1}_{t}=\beta_{1}+\beta_{2} \cdot G S 1+\beta_{3} \cdot G S 2+\beta_{4} \cdot G S 3+\beta_{5} \cdot G S 4+\beta_{6} \cdot G S 5+\beta_{7} \cdot V L E 1+\beta_{8} \cdot V L E 2+\beta_{9} \cdot V L E 3+\varepsilon$} \\
\hline \multirow[t]{2}{*}{ R2 } & STF2 & GS1, GS2, GS5 & VLE1, VLE2, VLE3, VLE4, VLE7 & STF1 \\
\hline & \multicolumn{4}{|c|}{$\begin{array}{l}S T F 2_{t}=\beta_{1}+\beta_{2} \cdot G S 1+\beta_{3} \cdot G S 2+\beta_{4} \cdot G S 5+\beta_{5} \cdot V L E 1+\beta_{6} \cdot V L E 2+\beta_{7} \cdot V L E 3+\beta_{8} \cdot V L E 4+\beta_{9} \cdot V L E 7+\beta_{10} \cdot \\
S T F 1+\varepsilon\end{array}$} \\
\hline \multirow[t]{2}{*}{ R3 } & STF3 & GS1, GS2, GS4, GS5 & VLE2, VLE7 & STF1, STF2 \\
\hline & \multicolumn{4}{|c|}{ STF $3_{t}=\beta_{1}+\beta_{2} \cdot G S 1+\beta_{3} \cdot G S 2+\beta_{4} \cdot G S 4+\beta_{5} \cdot G S 5+\beta_{6} \cdot V L E 2+\beta_{7} \cdot V L E 7+\beta_{8} \cdot S T F 1+\beta_{9} \cdot S T F 2+\varepsilon$} \\
\hline \multirow[t]{2}{*}{ R4 } & STF4 & GS1, GS2 & VLE1, VLE2, VLE7 & STF1, STF2 \\
\hline & \multicolumn{4}{|c|}{ STFH $_{t}=\beta_{1}+\beta_{2} \cdot G S 1+\beta_{3} \cdot G S 2+\beta_{4} \cdot V L E 1+\beta_{5} \cdot V L E 2+\beta_{6} \cdot V L E 7+\beta_{7} \cdot S T F 1+\beta_{8} \cdot S T F 2+\beta_{9} \cdot S T F 3+\varepsilon$} \\
\hline \multirow[t]{2}{*}{ R5 } & STF5 & GS1, GS2, & VLE2, VLE7 & STF1, STF2, STF3, STF4 \\
\hline & \multicolumn{4}{|c|}{ TF5 $_{t}=\beta_{1}+\beta_{2} \cdot G S 1+\beta_{3} \cdot G S 2+\beta_{4} \cdot V L E 2+\beta_{5} \cdot V L E 7+\beta_{6} \cdot$ STF1 $+\beta_{7} \cdot$ STF2 $+\beta_{8} \cdot$ STF $3+\beta_{9} \cdot$ STF $4+\varepsilon$} \\
\hline
\end{tabular}

defenders, contributes some practical aspects to the process of education through ICT supported by various studies. However, it is debatable whether the success of online learning processes is conditioned by the perception that students have about it and the satisfaction upon completing it. Likewise, it may be that the students' own individual abilities can condition their performance in the VLE and, as a consequence, their satisfaction with learning. Thus, such generic abilities of each student could condition the success of the VLE.

In this paper, students' perceptions of the three variables that could be conditioning the success of the learning process were analysed; these three variables are the attitude towards VLE, the self-perception of students related to their generic skills, and the satisfaction with the learning process.

The first results of the analysis indicate that the students showed a high positive evaluation in the self-perception about their generic skills. Likewise, students perceived the VLE in a very favourable way, expressing their agreement with most of its aspects. The students also stated that they perceive a high score of satisfaction with learning, both for the results and for other aspects, such as the usefulness of the knowledge, the time spent on the online course and other aspect related to both variables. Overall, the results seem to indicate that students who perceive their generic abilities as high are also satisfied with the learning process and with the VLE.

These preliminary conclusions, together with the validity of the three constructors analysed, allow one to plan a future analysis of how the weight of the different variables represented by each constructor (VLE, STF and GS) can be decisive in an educational model. An understanding of these aspects could determine the success of the VLE, and, in the end, the success of the educational programme, making it easier to achieve a satisfactory academic performance.

Table 15 Model Summary $R 1^{\text {b }}$

\begin{tabular}{lllllc}
\hline Model & $R$ & R Square & Adjusted R Square & Std. Error of the Estimate & Durbin-Watson \\
\hline 1 &, $563^{\text {a }}$ &, 317 &, 274 &, 732 & 1794 \\
\hline
\end{tabular}

apredictors: (Constant), VLE3, GS4, GS3, GS2, VLE1, GS5, VLE2, GS1

${ }^{\text {b}}$ Dependent Variable: STF1 
Table 16 ANOVA R1 $1^{\mathrm{a}}$

\begin{tabular}{lllllll}
\hline Model & & Sum of Squares & df & Mean Square & $F$ & Sig. \\
\hline 1 & Regression & 31,126 & 8 & 3891 & 7263 &, $000^{\mathrm{b}}$ \\
& Residual & 66,964 & 125 &, 536 & & \\
& Total & 98,090 & 133 & & & \\
\hline
\end{tabular}

Dependent Variable: STF1

bPredictors: (Constant), VLE3, GS4, GS3, GS2, VLE1, GS5, VLE2, GS1

Table 17 Model Summary R2 ${ }^{\mathrm{b}}$

\begin{tabular}{lllllc}
\hline Model & $R$ & R Square & Adjusted R Square & Std. Error of the Estimate & Durbin-Watson \\
\hline 1 &, $670^{\text {a }}$ &, 449 &, 409 &, 814 & 1888 \\
\hline
\end{tabular}

Predictors: (Constant), STF1, VLE4, VLE7, GS5, GS2, VLE1, VLE2, VLE3, GS1

bependent Variable: STF2

Table 18 ANOVA R2 ${ }^{\mathrm{a}}$

\begin{tabular}{lllllll}
\hline Model & & Sum of Squares & df & Mean Square & $F$ & Sig. \\
\hline 1 & Regression & 66,811 & 9 & 7423 & 11,209 &, $000^{\circ}$ \\
& Residual & 82,122 & 124 &, 662 & & \\
& Total & 148,933 & 133 & & &
\end{tabular}

Dependent Variable: STF2

bPredictors: (Constant), STF1, VLE4, VLE7, GS5, GS2, VLE1, VLE2, VLE3, GS1

Table 19 Model Summary R3 ${ }^{\mathrm{b}}$

\begin{tabular}{llllll}
\hline Model & $R$ & R Square & Adjusted R Square & Std. Error of the Estimate & Durbin-Watson \\
\hline 1 &, $724^{\text {a }}$ &, 525 &, 494 &, 649 & 1957
\end{tabular}

a Predictors: (Constant), STF2, GS4, VLE2, GS2, GS5, VLE7, STF1, GS1

${ }^{b}$ Dependent Variable: STF3

Table 20 ANOVA R3 ${ }^{a}$

\begin{tabular}{lllllll}
\hline Model & & Sum of Squares & df & Mean Square & $F$ & Sig. \\
\hline 1 & Regression & 58,135 & 8 & 7267 & 17,243 &, $000^{5}$ \\
& Residual & 52,679 & 125 &, 421 & \\
& Total & 110,813 & 133 & & \\
\end{tabular}

${ }^{a}$ Dependent Variable: STF3

'Dredictors: (Constant), STF2, GS4, VLE2, GS2, GS5, VLE7, STF1, GS1

Table 21 Model Summary (R4)

\begin{tabular}{lllllc}
\hline Model & $\mathrm{R}$ & $\mathrm{R}$ Square & Adjusted R Square & Std. Error of the Estimate & Durbin-Watson \\
\hline 1 &, $810^{\mathrm{a}}$ &, 657 &, 635 &, 567 & 2395 \\
\hline $\begin{array}{l}\text { aPredictors: (Constant), STF3, VLE1, GS2, VLE7, VLE2, STF2, GS1, STF1 } \\
\text { be }\end{array}$ & &
\end{tabular}


Table 22 ANOVA (R4) ${ }^{a}$

\begin{tabular}{lllllll}
\hline Model & & Sum of Squares & df & Mean Square & $F$ & Sig. \\
\hline 1 & Regression & 76,779 & 8 & 9597 & 29,883 &, $000^{b}$ \\
& Residual & 40,146 & 125 &, 321 & & \\
& Total & 116,925 & 133 & & & \\
\hline
\end{tabular}

a Dependent Variable: STF4

bPredictors: (Constant), STF3, VLE1, GS2, VLE7, VLE2, STF2, GS1, STF1

Table 23 Model Summary R5

\begin{tabular}{lllll}
\hline Model & $\mathrm{R}$ & R Square & Adjusted R Square & Std. Error of the Estimate \\
\hline 1 &, $816^{\mathrm{a}}$ &, 666 &, 645 &, 598
\end{tabular}

apredictors: (Constant), STF4, VLE2, GS1, VLE7, STF2, GS2, STF3, STF1

Table 24 ANOVA R5 ${ }^{a}$

\begin{tabular}{lllllll}
\hline Model & & Sum of Squares & df & Mean Square & $F$ & Sig. \\
\hline 1 & Regression & 89,242 & 8 & 11,155 & 31,175 &, $000^{\circ}$ \\
& Residual & 44,728 & 125 & ,358 & & \\
& Total & 133,970 & 133 & & & \\
\hline
\end{tabular}

${ }^{\mathrm{a} D e p e n d e n t ~ V a r i a b l e: ~ S T F 5 ~}$

Predictors: (Constant), STF4, VLE2, GS1, VLE7, STF2, GS2, STF3, STF1

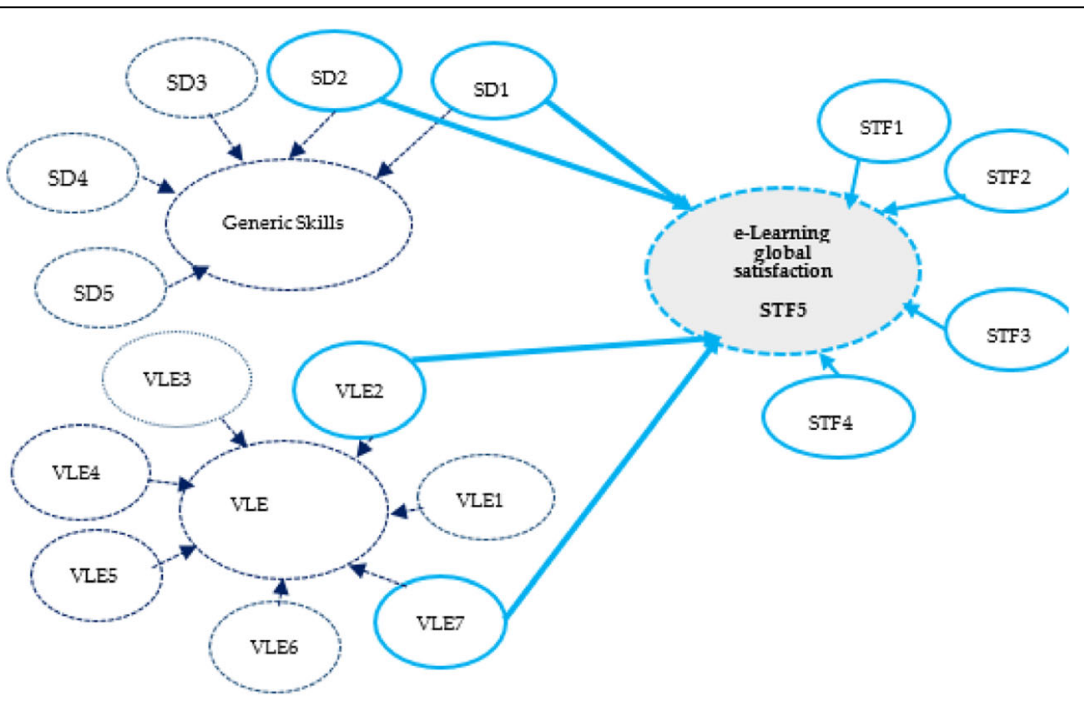

Source: own development by SPSS

Fig. 3 Model for global satisfaction (STF5): R5 
According to the explanatory effect of certain competences related to the ability to solve problems and the analytical capacity in the global satisfaction with the teaching-learning process in VLE, it is necessary to continue the analysis of these variables by replicating the study using similar teaching environments and with other subjects.

In addition, this result also allows actions to be taken to monitor and reinforce the students with the lowest profiles in these competences. These educational actions would also be applicable to students with low profiles in affinity to computerized environments or those with a lower capacity for study self-organization.

In short, we consider these findings useful for expanding the knowledge of the factors that determine the satisfaction with the learning processes when it is strongly supported by a VLE, especially in subjects requiring a high analytical and numerical capacity, such as accounting. These results can open a line of research aimed at improving learning outcomes in subjects with similar characteristics.

Acknowledgements

Referees (At the end of a future process of review).

Funding

Not applicable.

\section{Availability of data and materials}

The datasets generated and analysed in the current study are not publicly available because they were collected under students' authorization and anonymity, using data only for teaching and scientific research purposes.

Authors' contributions

All the authors have made the same contribution to the paper. All authors read and approved the final manuscript.

Competing interests

The authors declare that they have no competing interests.

\section{Publisher's Note}

Springer Nature remains neutral with regard to jurisdictional claims in published maps and institutional affiliations.

\section{Author details}

${ }^{1}$ Department of Business Economics and Accounting, Faculty of Economics and Business, Universidad Nacional de Educación a Distancia (UNED), Madrid, Spain. ${ }^{2}$ Department of Business Management and Sociology, Faculty of Economics and Business, Badajoz, Spain.

Received: 3 October 2018 Accepted: 26 April 2019

Published online: 04 June 2019

\section{References}

Al Ghamdi, A., Samarji, A., \& Watt, A. (2016). Essential considerations in distance education in KSA: Teacher immediacy in a virtual teaching and learning environment. International Journal of Information and Education Technology, 6(1), 17.

Alsadoon, H. (2017). Students' perceptions of E-assessment at Saudi Electronic University. Turkish Online Journal of Educational Technology, (1), 16, 147-153.

Al-Samarraie, H., Teng, B. K., Alzahrani, A. I., \& Alalwan, N. (2017). E-learning continuance satisfaction in higher education: A unified perspective from instructors and students. Studies in Higher Education, 3(11), 2003-2019.

Arbaugh, J. B. (2000). Virtual classroom characteristics and student satisfaction with internet-based MBA courses. Journal of Management Education, 24(1), 32-54.

Boza, A., \& Toscano, M. (2012). Motivos, actitudes y estrategias de aprendizaje: aprendizaje motivado en alumnos universitarios. Profesorado. Revista de Currículum y Formación del Profesorado, 16(1), 125-142.

Brecht, H. D. (2012). Learning from online video lectures.

Brecht, H. D., \& Ogilby, S. M. (2008). Enabling a comprehensive teaching strategy: Video lectures. Journal of Information Technology Education, 7, 71-86.

Byrne, M., Flood, B., \& Willis, P. (2002). The relationship between learning approaches and learning outcomes: A study of Irish accounting students. Accounting Education, 11(1), 27-24.

Cabero, J., Llorente, C., \& Puentes, A. (2010). La satisfacción de los estudiantes en red en la formación semipresencial, Comunicar, V. XVIII, $n^{\circ} 35$ (pp. 149-157).

Cano González, R. (2009). Tutoría universitaria y aprendizaje por competencias ¿Cómo lograrlo? Revista Electrónica Interuniversitaria de Formación del Profesorado, 28(12-1), 181-204. 
Cassidy, S. (2016). Virtual learning environments as mediating factors in student satisfaction with teaching and learning in higher education. Journal of Curriculum and Teaching, 5(1), 113.

Castillo, A... S. (2008). Tutoría de la UNED ante los nuevos retos de la convergencia europea. Revista Interuniversitaria de Formación del Profesorado, (61), 139-165.

Chang, C. T., Hajiyev, J., \& Su, C. R. (2017). Examining the students' behavioral intention to use e-learning in Azerbaijan? The general extended technology acceptance model for e-learning approach. Computers \& Education, 111, 128-143.

Chen, C. C., \& Jones, K. T. (2007). Blended learning vs. traditional classroom settings: Assessing effectiveness and student perceptions in an MBA accounting course. Journal of educators online, 4(1), n1.

Chen, I. Y., Chen, N. S., \& Kinshuk (2009). Examining the factors influencing participants' knowledge sharing behavior in virtual learning communities. Journal of Educational Technology \& Society, 12(1), 134.

Chen, K. T. C. (2017). Examining EFL instructors' and students' perceptions and acceptance toward M-learning in higher education. Universal Access in the Information Society, 16(4), 967-976.

Chiu, C. M., Hsu, M. H., \& Sun, S. Y. (2005). Usability, quality, value and e-learning continuance decisions. Computers \& Education, 45, 399-416.

Conati, C. (2002). Probabilistic assessment of user's emotions in educational games. Journal of Applied Artificial Intelligence, 16(7/8), 555-575.

Cortina-Pérez, B. (2008). Teaching and learning English through WebCT tools: Promoting digital scaffolding. The International Jour nal of Technology Knowledge and Society, 2(5), 129-138.

Enoch, Y., \& Soker, Z. (2006). Age, gender, ethnicity and the digital divide: University students' use of web-based instruction. Open Learning: The Journal of Open, Distance and E-Learning, 21(2), 99-110.

Frías-Navarro, D. (2014). Apuntes de SPSS. Universidad de Valencia, Spain, Retrieved from http://www.uv.es/friasnav/ ApuntesSPSS.pdf (2014 may 5).

Gámiz-Sánchez, V., \& Gallego-Arrufat, M. J. (2016). Modelo de análisis de metodologías didácticas semipresenciales en Educación Superior. Educación XX1, 19(1), 39-61. https://doi.org/10.5944/EducXX1.13946.

Garrison, D. R., \& Anderson, T. (2005). El e-learning en el siglo XXI: Investigación y práctica. Barcelona: Octaedro.

George, D., \& Mallery, P. (2003). SPSS for windows step by step: A simple guide and reference. 11.0 update, (4th ed., ). Boston: Allyn \& Bacon.

Hall, M., Ramsay, A., \& Raven, J. (2004). Changing the learning environment to promote deep learning approaches in first-year accounting students. Accounting Education, 13(4), 489-505.

Harnar, M. A., Brown, S. W., \& Mayall, H. J. (2000). Measuring the effect of distance education of the learning experience: Teaching accounting via Picturetel. International Journal of Instructional Media, 27(1), 37.

Henderson, M., Selwyn, N., \& Aston, R. (2017). What works and why? Student perceptions of 'useful' digital technology in university teaching and learning. Studies in Higher Education, 42(8), 1567-1579.

Herrador-Alcaide, T. C., \& Hernández-Solís, M. (2016). Educación Digital Contable mediante Redes de Innovación: Una Medición de su Impacto. Digital Education Review, (29), 247-264.

Herrador-Alcaide, T. C., \& Hernández-Solís, M. (2017). Numerical-technological skills and work experience in the perceived usefulness in an accounting virtual learning environment. Turkish Online Journal of Educational Technology-TOJET, 16(3), 116-131.

Holtzblatt, M., \& Tschakert, N. (2011). Expanding your accounting classroom with digital video technology. Journal of Accounting Education, 29(2), 100-121.

Hurtado, M. D. M. D., \& Lara, L. Á. C. (2015). Efectividad del aprendizaje cooperativo en contabilidad: una contrastación empírica. Revista de Contabilidad, 18(2), 138-147.

Johnston, J., Killion, J., \& Oomen, J. (2005). Student satisfaction in the virtual classroom. The Internet Journal of Allied Health Sciences and Practice, 3(2), 6.

Kang, M., Park, M., Jung, J., \& Park, H. (2009). The effect of interaction and learning presence on learning outcome in webbased project learning. Journal of Educational Information and Media, 15, 67-85.

Kavanagh, M. H., \& Drennan, L. (2008). What skills and attributes does an accounting graduate need? Evidence from student perceptions and employer expectations. Accounting \& Finance, 48(2), 279-300.

Kreijns, K., Kirschner, P., \& Jochems, W. (2003). Identifying the pitfalls for social interaction in computer-supported collaborative learning environments: A review of the research. Computers in Human Behavior, 19, 335-353.

Kurelovic, E. K. (2016). Advantages and limitations of usage of open educational resources in small countries. International Journal of Research in Education and Science (IJRES), 2(1), 136-142.

Levy, M. (2007). Technologies in use for second language learning. The Modern Language Journal, 93(s1), 769-782.

Li, N., Marsh, V., Rienties, B., \& Whitelock, D. (2016). Online learning experiences of new versus continuing learners: A largescale replication study. Assessment \& Evaluation in Higher Education, 1e16. https://doi.org/10.1080/02602938.2016.1176989.

Loewnthal, K. M. (1996). An introduction to psychological tests and scales. London: UCL Press.

Martínez, P., Pérez, J., \& Martínez, M. (2016). Las TIC y el entorno virtual para la tutoría universitaria. Educación XX1, 19(1), 287310. https://doi.org/10.5944/EducXX1.13942.

Martínez-Cerdá, J. F., Torrent-Sellens, J., \& González-González, I. (2018). Promoting collaborative skills in online university: Comparing effects of games, mixed reality, social media, and other tools for ICT-supported pedagogical practices. Behaviour \& Information Technology, 37(10-11), 1055-1071.

Martins, L. L., \& Kellermanns, F. W. (2004). A model of business school students' acceptance of a web-based course management system. Academy of Management Learning \& Education, 3(1), 7-26.

Mensah, F. S. (2017). Ghanaian tertiary students' use of ICT. Global Journal of Human-Social Science Research, 1(9).

Monereo, C. (2007). Hacia un nuevo paradigma del aprendizaje estratégico: la mediación social, el yo, y las emociones. Electronic Journal of Research in Educational Psychology, 5(13), 497-534.

Navimipour, N. J., \& Zareie, B. (2015). A model for assessing the impact of e-learning systems on employees' satisfaction. Computers in Human Behavior, 53, 475-485.

Nunnally, J. C. (1967). Psychometric theory. New York: McGraw Hill.

Nunnally, J. C. (1978). Psychometric theory, (2nd ed., ). New York: McGraw Hill.

Oosterhoff, A., Conrad, R. M., \& Ely, D. P. (2008). Assessing learners online. Upper Saddle River: Pearson Prentice Hall.

Palacios, T. M. B., \& Galván, R. S. (2003). Gestión del conocimiento y estrategia. Revista Madrit d, (19), 4. 
Pituch, K. A., \& Lee, Y. (2006). The influence of system characteristics on e-learning use. Computers \& Education, 47, 222-244.

Potter, B. N., \& Johnston, C. G. (2006). The effect of interactive on-line learning systems on student learning outcomes in accounting. Journal of Accounting Education, 24(1), 16-34.

Requena, B. E. S. (2016). Las TIC y la Educación Social en el siglo XXI. EDMETIC, 5(1), 8-24

Richardson, J. C., Maeda, Y., LV, J., \& Caskurlu, S. (2017). Social presence in relation to students' satisfaction and learning in the online environment: A meta-analysis. Computers in Human Behavior, 71, 402-417.

Rodríguez, G., \& Ibarra, M. S. (2011). e-Evaluación orientada al e-aprendizaje estratégico en educación superior. Madrid: Narcea. Santos, I. M., \& Ali, N. (2012). Exploring the uses of mobile phones to support informal learning. Education and Information Technologies, 17(2), 187-203. https://doi.org/10.1007/s10639-011-9151-2.

Sharples, M. (2000). The design of personal mobile technologies for lifelong learning. Computers \& Education, 34(3-4), 177-193.

Soto, F. J., \& Fernández, J. J. (2003). Realidades y retos de inclusión digital. Comunicación y Pedagogía, nº (192), 34-40.

Stanley, T., \& Edwards, P. (2005). Interactive multimedia teaching of accounting information system (AIS) cycles: Student perceptions and views. Journal of Accounting Education, 23(1), 21-46.

Swain, J., \& Hammond, C. (2011). The motivations and outcomes of studying for part-time mature students in higher education. International Journal of Lifelong Education, 30(5), 591-612.

Tett, L. (2004). Mature working-class students in an 'elite'university: Discourses of risk, choice and exclusion. Studies in the Education of Adults, 36(2), 252-264.

United Nations Educational, Scientific and Cultural Organisation (UNESCO). (2002). Forum

Van Raaij, E. M., \& Schepers, J. J. (2008). The acceptance and use of a virtual learning environment in China. Computers \& Education, 50(3), 838-852.

Van Rhijn, T., Lero, D., Bridge, K., \& Fritz, V. (2016). Unmet needs: Challenges to success from the perspectives of mature university students.

Van Wyk, M. M. (2017). Exploring student teachers' views on eportfolios as an empowering tool to enhance self-directed learning in an online teacher education course. Australian Journal of Teacher Education, 42(6), 1.

Viberg, O., \& Grönlund, A. (2013). Cross-cultural analysis of users' attitudes toward the use of mobile devices in second and foreign language learning in higher education: A case from Sweden and China. Computers \& Education, 69, 169-180.

Violante, M. G., \& Vezzetti, E. (2015). Virtual interactive e-learning application: An evaluation of the student satisfaction. Computer Applications in Engineering Education, 23(1), 72-91.

Wu, J. H., Tennyson, R. D., \& Hsia, T. L. (2010). A study of student satisfaction in a blended e-learning system environment. Computers \& Education, 55(1), 155-164.

Wu, J. H., \& Wang, S. C. (2005). What drives mobile commerce? An empirical evaluation of the revised technology acceptance model. Information \& Management, 42, 719-729.

\section{Submit your manuscript to a SpringerOpen ${ }^{\circ}$ journal and benefit from:}

- Convenient online submission

- Rigorous peer review

- Open access: articles freely available online

- High visibility within the field

- Retaining the copyright to your article

Submit your next manuscript at $\boldsymbol{s p r i n g e r o p e n . c o m ~}$ 